\title{
Iran-Turkey Relations in the 2000s: Pragmatic Rapprochement
}

\author{
Nilüfer KARACASULU' ${ }^{1}$ İrem AŞKAR KARAKIR²
}

\begin{abstract}
The AK Party government's Middle Eastern approach indicated a change from those of previous governments. Whilst aiming to conduct an active and influential political role in the Middle East, they have attempted to achieve 'zero problems' in their relations with neighbors as well as closer contact. This article examines Turkey's relations with one of the states in the region - Iran. Under modified regional policy, the Turkish government aimed to maintain and expand relations with Iran. Particularly, strategic calculations on security, energy and economy are influential in transformation of the Turkish attitude towards Iran. At the same time, Iran appears willing to improve relations with Turkey for pragmatic reasons. What is evident for both countries is that though they both are tempting to improve mutual relations, they are at the same time searching ways to consolidate their regional role. In this connection, this article argues that there is a pragmatic rapprochement between the two countries. (153 words)
\end{abstract}

Key Words: Turkey-Iran relations, Turkish foreign policy, AK Party government, Iranian foreign policy, Middle East

\section{INTRODUCTION}

Since its rise to power in 2002, the current AK Party government in Turkey has given high priority to the Middle East in foreign policy. (Bar, 2006; 2) It appears that they have relatively placed more emphasis to the Middle East than previous governments. Under the modified regional policy, they have been engaged in an active dialogue and closer contact with Turkey's southeastern neighbor - Iran, while also developing relations with other southeastern neighbors - Syria and Iraq. Particularly increasing partnership with Iran is a critical issue for Turkey's long-standing ally the US, because there is high concern on the Iranian nuclear program. In this connection, progress of relations between Turkey and Iran is widely discussed in media in the last years, especially after the official visits. There were high-level official visits between Turkey and Iran, such as the visit of Turkish Deputy Foreign Minister Ertugrul Apakan to Iran in June 2008, Iranian Foreign Minister Mottaki to Ankara in July 2008, Turkish Foreign Minister Ali Babacan to Iran in the same month, Iranian President Ahmedinejad to Istanbul in August 2008, Iranian Parliament speaker Ali Larijani to Turkey in January 2009 and Turkish Prime Minister Erdogan to Iran in October 2009. These visits are considered as signs of two sides' willingness to improve bilateral relations.
Nevertheless, scholarly literature about the recent relations between the two countries is limited. Specifically, Robert Olson has examined the bilateral relations in depth until the mid 2000's. (Olson, 2004, 2002a, 2002b, 2000) Calabrese (1998) have analyzed Turco-Iranian relations in the 1990s. Furthermore, Efegil and Stone (2003) and Aras (2001) focused on the bilateral relations in the early years of AK Party government. To further elaborate bilateral relations in the 2000s, this article analyses recent rapprochement between Turkey and Iran from a critical perspective. In analyzing recent bilateral relations, the article tries to provide key generalizations regarding their approach to each other.

Firstly, history of bilateral relations is briefly reviewed so as to enhance our perception about recent relations. Secondly, this study puts forward regional policies of each state. From engagements of the government in the region and from the speeches of Ahmet Davutoglu, the former chief advisor to the current Turkish Prime Minister and the present Foreign Minister, in general it is obvious that the AK Party government aims to conduct an active and influential political role in the Middle East. Yet, in particular towards Iran, Turkey has behaved with the logic of realpolitik based on strategic national interests. On the other side, if we direct our attention

\footnotetext{
${ }_{1}^{1}$ Assoc. Prof., Dokuz Eylül University, Faculty of Business, Department of International Relations, nilufer.karaca@deu.edu.tr

${ }^{2}$ Research Assistant, Dokuz Eylül University, Faculty of Business, Department of International Relations, irem.askar@deu.edu.tr
} 
to Iran, it is observed that Iran has been trying to strengthen its regional relations for pragmatic reasons. The changing overall context of relations in the Middle East also facilitates development of mutual relations. The recent derivers of TurkeyIran relations are examined in the third section. In conclusion, there is rapprochement between the two countries in the 2000s since they have mutual interests. Yet, this article argues that there is a cautious and pragmatic rapprochement between Turkey and Iran, because Turkey appears determined to consolidate its regional position as well as Iran.

\section{BRIEF HISTORICAL BACKGROUND OF BILATERAL RELATIONS UNTIL 2002}

Turkey and Iran -being neighbors with 310-mile border- are belonging two different sects as Sunni and Shii and have different regimes as secular and theocratic. In general Turkey-Iran relations can be examined in three phases. The first phase is between 1920 and 1970, in which the relations were reasonably good. The second phase is between 1979 and 2002, in which the relations were problematic. The third phase covers since 2002 until present, in which the relations have been relatively good.

In the first phase, Turkey and Iran pursued similar foreign policy goals, and thus signed the Treaties of Friendship and Security in 1926 and 1932, and formed the Saadabad Pact in 1937. After the Second World War both countries followed a policy of alliance with the West. Furthermore, when Turkey and Iraq signed the Baghdad Pact in 1955 to prevent the Soviet intervention, Iran also joined the Pact. After Iraq pulled out, the name of the Pact was changed to the Central Treaty Organization (CENTO) in 1959, and survived until 1979. In short, Iran and Turkey continued their cooperation until the Iranian Revolution in 1979 and as Bishku (1999) argues bilateral relations were reasonably good with similar foreign policy principles.

The second phase starts with the Iranian Revolution. After the Revolution as the two countries started to follow contradictory ideological poles, there was a remarkable change in bilateral relations. Turkey started to conceive threats coming from Iran. Turkey felt threatened, because firstly during the 1980s and 1990s Iran became the main sponsor of PKK (the Kurdistan Worker's Party) terrorism (Laqueur, 2002; 172); secondly, there were attempts of Iran to export the Iranian revolution (Emerson and Tocci, 2004; 24-25, Byman et. al., 2001; 65-66, Ozcan, 1999, Karmon, 1997); thirdly, there were claims on Iranian involvement in political assassination of the Turkish intellectuals by training the radical Islamist groups in Turkey. (Ozacan, 2004; 8) Thus, there was high tension and serious problems between the two countries. In this period, during the Iran-Iraq war from 1980 until 1988, Turkey maintained neutrality. At the same time, both Iran and Turkey have valued the economic partnership, which resulted with expansion of trade between the two countries. (Calabrese, 1998; 78) Yet, despite economic cooperation, other problems remained and became significant particularly toward the end of the 1980's.

Furthermore, following the collapse of the Soviet Union, Iran and Turkey were engaged in competition to influence over Central Asia and the Caucasus, and to increase their economic and political relations with the new Republics. A Turkish world from the Adriatic to the Chinese wall became a slogan in Turkish foreign policy. However, towards the mid 1990s, it became obvious that Russia would not tolerate their regional influence, thus limiting the two countries competition and engagement over Eurasia. (Efegil and Stone, 2003; 58)

Nevertheless, towards the end of the 1990s, Turkey's perceived threats from Iran have diminished (Emerson and Tocci, 2004; 25), because with President Khatami's government in 1997 Iran's quest to export the Revolution and the support for the radical Islamist groups and PKK terrorism had gradually declined (Laqueur, 2002; 175). Thus, Turkey began to approach Iran more tolerably. (Olson, 2000) But this optimism was short lived, because the Azerbaijani-Armenian conflict in Nagorno-Karabakh which has gradually increased after the dissolution of the Soviet Union starting from the early 1990s, broke out into war in 1992, and once again PKK terrorism dominated bilateral relations. (Olson, 2002a) In contradiction to each other, Iran supported Armenia (Olson, 2002b; 61-85), while Turkey supported Azerbaijan. Incidentally, Iran wanted to prevent the increase of Turkey's influence in Central Asia and Caucasus, since a competition between the two countries has started to become main energy route in transportation of the Central Asian energy sources to the world market. But, despite conflicting interests two countries have avoided serious confrontation. (Efegil and Stone, 2003)

Though there were contradictions and problems in relations in the second phase, there was a remarkable change particularly after 2002. (Olson, 2004; 242-243) The following sections will try to elaborate the third phase in bilateral relations. 


\section{TURKEY'S REGIONAL FOREIGN POLICY VERSUS IRAN'S}

Iran and Turkey are two major regional powers that might have significant role in the Middle East. Firstly, we will focus on Turkey's regional foreign policy. Turkey appears to be searching for an international actor role in world politics through adapting a new foreign policy approach. Under this new approach, alliance with the West is no more considered as the first priority as in previous era. Rather this new approach assigns value to the East as much as the West. Since 2002, the AK Party government has adopted a 'zero-problem policy' (win-win) toward neighboring countries for developing political and economic relations. (Davutoglu, 2008) Particularly under the rule of the AK Party, Turkey has developed close ties with Iran, Syria, Sudan, Saudi Arabia, Qatar and Russia. The AK Party government is also in pursuit of increasing Turkey's influence in the neighboring regions, namely in Central Asia and the Middle East. As indicated by Davutoglu (2008), the AK Party government is willing to increaseTurkey's geopolitical standing by becoming particularly an energy hub and a facilitator in regional conflicts, while also increasing cooperation with neighbors in other subjects such as trade and tourism. In short, with Davutoglu's vision Turkey has been trying to strengthen its regional role and influence. Structural changes around Turkey also have given an opportunity to adopt a more active approach.

This new policy understanding is a departure from traditional orientation, in which Turkey avoided to get involved in regional affairs and adopted a very cautious approach due to insecurity of the neighborhood. Thus, in the recent years a reorientation in Turkish foreign policy is apparent. (Bar, 2006, Cagatay, 2009) As indicated by Aras and Polat (Aras and Polat, 2007; 483), with this new activism Turkey aims to become an influential diplomatic actor by being a regional peacemaker or a facilitator in regional conflicts. (Larrabee, 2007; 103) If successful, it is considered that this might increase Turkey's soft power in the Middle East. (Altunisik, 2008)

By this shift toward active engagement with the Middle East, Turkey opted for a facilitator role between the international community and Iran. In June 2006, the Turkish Foreign Minister Abdullah Gul during his visit to Tehran told that Turkey could be a facilitator between Iran and the international community. In this connection, Oguzlu (2007; 93-94) pointed out that Turkey's soft power identity could become visible through Turkey's efforts to help facilitate a dialogue between Iran and the West. However, it is still not clear whether Iran will accept Turkey as a facilitator. Though it is not possible to argue that Turkey would be 'an acceptable' facilitator in regional conflicts, it is evident that it is one of the main pillars of the present regional foreign policy.

The second pillar of present regional foreign policy is becoming a major Eurasian energy corridor and energy hub -that is by oil and gas transportation from energy-rich Central Asia and the Caucasus to energy-demanding European states through the Baku-Tblisi-Ceyhan (BTC), Blue Stream (BS), Nabucco and Samsun-Ceyhan (SC) pipelines. [2] But Turkey needs to build its infrastructure for storing and reexporting gas to Europe. BOTAS, the state owned gas company in Turkey, cannot make these investments alone, because these pipelines are very expensive to build. Besides, though the government is aware of the need for energy market reform, there has been little progress because of political disagreements. (Barysch, 2007) In short, again it is still not clear if Turkey would accomplish this strategy.

Nevertheless, overall, it is evident that Turkey is in search for improving its regional relations. Does this signify a turn away from the Western alliance? When this question was directed to President Gul, he replied that, "a country's direction is determined by its values, and not by its relations. Important point is in which direction Turkey's values develop. These are democratic values, respect for law, equality of men and women, liberal economy and so on. These better show in which direction Turkey is going." (Sarikaya, 2009) President Gul further indicated that the AK Party government's foreign policy is based on ethics and morality. (Sarıkaya, 2009) Thus, according to President Gul developing relations with neighbor countries does not signify avert from the Western values. However, though values are kept, there is some change in the attitude as indicated by Prime Minister Erdogan. After his visit to Tehran in October 2009 , he told that one side of Turkey's face is directed toward the West and other side toward the East. (Ozel, 2009) Thus, according to Erdogan rather than departing from the West, new approach accepts the Eastern relations as valuable as the Western relations. What can be underlined is that rather than following a regional foreign policy based on the Western alliance, the AK Party government prefers to liberate itself from this domination. While the ties with traditional allies have cooled, empathy towards the Middle Eastern countries has increased. Overall, Turkey is searching for increased role and soft power in the Middle East. 
Furthermore, Turkey's relations with Iran under the AK Party rule attract the attention of the Western allies since Iran's criticism and opposition against the US is apparent. Moreover, Iran continues to develop its nuclear energy though faced by international community's opposition and economic embargo. With respect to Turkey's foreign policy towards Iran in general, while Turkey prefers to expand relations, pragmatic concerns rather than ideological intimacy determines its foreign policy strategy.

Turning our attention to Iran, it is observed that Iran's foreign policy towards the Middle East is based on a mix of ideological and pragmatic considerations. In fact, there is a clear ideological rhetoric as observed with the support given to Shiite Islamist groups. Iran has been assisting Lebanon's Hizbullah to confront Israel since its establishment in the early 1980s. Iranian support for training and material and organizational assistance has been significant in enhancing Hizbullah's power. (Chehabi, 2006; 259) In addition, Iran has supported Sunni Islamist groups including the Islamic Salvation Front (FIS) in Algeria and the Palestinian Islamist groups such as Hamas and Islamic Jihad. (Clawson and Rubin, 2005; 146) Following the collapse of the Saddam regime in Iraq, there has been a rise of Iranian influence in the Middle East. It seems that Iran has been trying to create a 'Shiite crescent,' given Iran's critical connections with the Shiite Islamist groups in Lebanon, in the Gulf States and lately in Iraq. (Gungor, 2008) Moreover, through providing passive and active support for the Shiite Islamist groups, Iran has been attempting to expand its sphere of political and cultural influence in Iraq, particularly in Najaf and Karbala, where population is predominantly Shii. Thus, there have been accusations raised by US authorities against Iran on training radical guerilla groups in camps near Iran-Iraq border.

However, even though these examples demonstrate a more ideology-oriented approach, there have been also some other cases illustrating a pragmatic Iranian approach. Iran's foreign policy towards Syria can be regarded in this respect (Ehteshami and Hinnebusch, 2002), which is based on security concerns of forming a strategic alliance against Israel. In addition, Iran's relations with Saudi Arabia a key ally of pro-Western camp in the Arab world, is a sign of pragmatism in Iranian foreign policy. Iran-Saudi Arabia relations have traditionally been described as hostile. Yet, particularly since the Iraq War, Iran has felt encircled by the existence of US coalition forces next to its borders, and thus tried to reduce tensions with Saudi Arabia. (Ramazani, 2004;
10)

Despite the conflicts between Iran and the US, today Iran has also relations with Iraq. President Talabani visited Iran for several times. Furthermore, Iranian President Ahmedinejad visited Iraq in March 2008. (Bilici, 2008) This was the first visit by an Iranian president after the Revolution in 1979. Despite the hostility between two countries, which lasted many years, Baghdad welcomed Iranian president, which openly condemns American presence in Iraq. Iraqi Prime Minister Nouri Maliki pointed out that their meeting had been "friendly, positive and full of trust." (BBC News, 2008)

Overall, Iran's foreign policy towards the Middle East accommodates a co-existence of idealism and pragmatism with a relative overweight of ideological references in rhetoric. However, ideological references in Iran's foreign policy towards the Middle East should not be overemphasized. A glance at Iranian policies that have been conducted in Lebanon and Iraq reveals Iran's religious rhetoric has not been free of strategic calculations. Even Iran's predominantly ideological foreign policy rhetoric towards Shiites in Lebanon, Iraq and the Gulf has contained elements of pragmatism.

With respect to Iran's foreign policy towards Turkey, it is fair to assert that pragmatic concerns have been influential. Improving relations with Turkey has been advantageous from Iran's point of view when the recent developments in the regional and the international context are taken into account. Iran has been suffering from economic isolation imposed by the UN and wants to increase its regional economic relations. Thus, expansion of relations with Turkey is rather beneficial for Iran. But as indicated by Haber Turk columnist Nihal Bengisu Karaca (2009), Iran might also has some hesitations since Turkey ideologically departs from Iran and has been an ally of the US. Iran has been closely watching the expansion of Turkey's influence particularly in the Middle East under the AK Party government, as well as Turkey's attempts to act as a mediator on the nuclear issue. Furthermore, though Iran cooperates with Turkey on several issues as will be examined in the next section, it rather seems that it does not want Turkey to be at the fore-front in regional domination.

\section{DERIVERS OF RECENT RELATIONS}

\subsection{Security}

Specifically, Iran and Turkey are preoccupied with a major similar security problem- PKK terrorism 
in Turkey and PJAK terrorism in Iran. Turkey's war on terror has a long history (Mango, 2005), while Iran has become a target of terrorism after the Iraq war. Particularly after the Iraq war in 2003, Turkey cooperated with Iran, because Iran as well as Turkey has been against increasing autonomy of Kurds in Iraq, given the potentially destabilizing effect on their own states. (Tank, 2005; 82, Ayman, 2006; 45) Turkey was against establishment of an independent Kurdish state in Northern Iraq and 'the Kurds to control the oil and gas fields of Northern Iraq.' (Olson, 2004; 165) Turkey's official policy has been to support the territorial integrity of Iraq. Meanwhile for Iran, resisting autonomy of Kurds in the region is considered as a part of their fight with US hegemony, as well as it is viewed as a security concern. Though earlier in the 1980s and 1990s Iran supported PKK terrorism in the Eastern borders of Turkey, in the 2000s it felt highly threatened from terrorism. Thus, both countries wanted to establish firmer control over their borders. In this respect, Turkey has considered Iran as an ally in its fight against PKK terrorism. (Ayman, 2006; 43, Uygur, 2008; 5) However, there is also a paradox. Though Iran has been sharing similar concerns with Turkey about Kurdish autonomy, also has not wanted 'the oil and gas of Northern Iraq to be controlled by Turkey'. (Olson, 2004; 165)

Even though main reason for both sides in recent security cooperation is concern about terrorism, there is also role of the external factors. After 2003 Iraq War, the US support for Turkey's fight with the PKK was jeopardized, especially due to protests of Iraqi Kurds and US fear of potential larger war. Moreover, Iran wanted to cooperate with Turkey because they had serious problems in their relations with the US. Iran wanted to maintain Turkey as a partner, keeping apart from the Western alliance against itself.

The two countries have been holding'High Security Commission Meetings' for more than a decade. During the Commission Meetings, they have discussed about bilateral cooperation in the fight against terrorism and border security. In one of the previous round of meetings in April 2008, the two countries signed a memorandum of understanding to promote their cooperation, and discussed measures on how to deal with threats posed by PKK and PJAK terrorism. (Haberturk Net, 2008). Thus, bilateral security cooperation improved in the last decade (Jenkins, 2008). The former commander of Turkey's land forces Ilker Basbug indicated that Turkey and Iran, even though not conducting joint operations against the terrorists, are sharing information and coordinating their operations. (TDN, 2008a)
Another critical security issue is the Iranian nuclear programme. Turkey is especially concerned about potential increase in the regional status and influence of nuclear (or near-nuclear) Iran in the Middle East. Ankara does not want proliferation of nuclear weapons in the region. Yet, the AK Party government has shied away from criticizing Iran's nuclear programme. In May 2008, Gregory Schulte, US Ambassador to the International Atomic Energy Agency, visited Ankara to discuss Iran's nuclear programme with the Turkish officials. The US expects to get support from the AK Party government to isolate Iran in the region. (Yetkin, 2008) Yet, Turkey does not agree with this policy. According to Turkish Foreign Minister Ali Babacan, rather than imposing sanctions and isolating Iran, Turkey prefers dialogue and diplomacy. (Reuters, 2008) Babacan repeated in July 2008 after a meeting with Iran's chief negotiator Saeed Jalili, Turkey has supported diplomacy to resolve the Iranian nuclear issue. (Associated Press, 2008) Based on this strategy, in May 2010, Turkey offered uranium swap deal together with Brazil.

Specifically Turkey supports the EU's 'constructive engagement policy' to convince Iran to freeze its uranium enrichment programme. Thus, Turkey has been interested in the EU/EU-3's attempts to engage in a dialogue with Iran. (Emerson and Tocci, 2004, Schleifer, 2006) Turkish Prime Minister Erdogan said, 'The continuation of Iran's nuclear programme for peaceful ends is a natural right, but it is impossible to support it if it concerns [the development] of weapons of mass destruction.' (Schleifer, 2006) In addition, President Abdullah Gul said, 'We don't want to see weapons of mass destruction in this region.' Similar to Erdogan he told that Iran had a right to develop nuclear energy but not nuclear weapons. (Guardian, 2008) Moreover, Foreign Minister Babacan said, 'We believe every sovereign country has the right to use nuclear energy for peaceful aims and to have that technology,' though Turkey is against nuclear proliferation in the region. (Associated Press, 2008)

No military action is expected in the shortrun against Iran, which is agreeable from Turkey's vantage point. Turkey would not favor a military strike by the US or increase of tension between the two sides. Specifically, Turkey prefers Iran not to continue its nuclear programme before convincing the international community about its peaceful intentions, and at the same time wishes that the international community would not engage in a military action against Iran. Overall, Turkey wants dialogue with Iran, and Iran without nuclear weapons. Nevertheless, today in Turkey, it is not totally clear if 
there are military plans for coping nuclear (or nearnuclear) Iran. Yet, we can say that if Iran gains nuclear power capabilities, Turkey with only conventional power capability might felt threatened. Furthermore, possession of nuclear weapons will enhance Iran's power and influence in the region whilst questioning the power and influence of Turkey.

Yet, Turkey is not acting along with theWestern allies on this issue for several reasons. Turkey has security and energy cooperation with Iran. Furthermore, Turkey itself wants to develop nuclear energy. Considering Turkey's revival for quest of nuclear energy, is Turkey in search for nuclear weapons? This would be a dramatic departure from long-standing Turkish policy and not expected. (Vick, 2006) Turkey has signed the Nuclear Non-Proliferation Treaty (NPT) and supported international efforts towards nonproliferation of weapons of mass destruction. As indicated by a Turkish expert on nuclear proliferation Kibaroglu (2008), Turkey should not try to possess nuclear weapons, which might in turn trigger nuclear proliferation in the region and endanger Turkish alliance with the West.

\subsection{Energy}

Turkey has very limited oil and gas reserves, thus searching for alternative resources. Currently, a Russian company Gazprom provides over half of Turkey's natural gas demand, which arbitrarily increases prices. Though Turkey tries to keep good relations with Russia, it also wants to diversify its energy resources and to decrease its dependency on Russia. (Barysch, 2007) In this respect, Iranian gas would reduce Turkey's dependence on Russian supplies. Iran provides close to a fifth of Turkey's natural gas supply. Turkey's dependency on the Iranian gas is 20 percent compared to 65 percent from Russia. (Turkey Analyst, 2008)

Turkey signed a memorandum of understanding with Iran in July 2007, in which it agreed to establish a joint company to carry up natural gas from Iran via Turkey to Europe and to construct three thermal power plants by Turkish companies in Iran. (The Economist, 2007) Yet, in August 2008, two sides failed to agree on a new deal on energy, since Turkish officials have told that Iran demanded pricing and investment conditions that they could not meet, but some analysts have claimed due to American pressure. In fact, the debate on choosing Iran as an energy partner is not new. Formerly, an energy agreement was signed between the two countries in 1996. Turkey signed another agreement with Iran in 2000 to import natural gas. (Associated Press, 2000)
US officials have been highly concerned over Turkey's energy contracts with Iran. Turkey has been aware of US concerns. Yet, due to domestic energy need Turkey seems decided to continue energy cooperation with Iran.

Earlier, in September 2007, at the UN General Assembly in New York, Turkish Prime Minister Erdogan held a meeting with President Ahmedinejad on planned natural gas deals, Iran's nuclear programme, and a joint combat operation plan against terrorism. Yet, the details of the meeting were not announced to public. At the same time, it was reported that Turkish Foreign Minister Babacan held a meeting with his US counterpart Rice on Turkey's energy cooperation with Iran, PKK terrorism and the Middle East Peace Process. These meetings were held just a day after the US adopted a bill to tighten economic sanctions against Iran. (TDN, 2007)

In contrast to US attitude, Iranian gas exports to Europe are of much interest to latter, since the EU wants to develop alternative energy resources to Russian option. (Emerson and Tocci, 2004) At present, the EU gets around a quarter of its gas from Russia. The European recent energy policy emphasizes diversification of sources of supply. Thus, pipeline connection from Iran is both in interest of Turkey and the EU.

Ironically, it might be possible for Iran to force Turkey to stay out of any Western efforts in containing Iran's disputed nuclear programme by using its dependence on Iranian gas supply. (The Christian Science Monitor, 2006) In fact, Iran arbitrarily cuts gas supply to Turkey without any acceptable excuse, leading to gas shortage in Turkey. For example, after an explosion on a gas pipeline, Iran reduced supplies in May 2008. (TDN, 2008b)

In short, Turkey's cooperation with Iran on energy deals has not been easy and efficient.

\subsection{Economy}

Economic relations among Turkey and Iran have accelerated in the last years. There is affect of both sides in the increase of economic relations. The imposition of UN sanctions and economic mismanagement of President Ahmedinejad administration have negative consequences for the Iranian economy. From Iran's vantage point, this has increased importance of economic relations with Turkey. Thus, Iran has even made legal reforms to increase its economic relations. At the same time, economic relations with Iran have become critical from Turkey's point of view since Turkey's need for energy resources has been rapidly increasing. Economic cooperation between Iran and 
Turkey has reached its peak in the last five years. (http://www.mfa.gov.tr) In 2008, Turkish exports to Iran comprised of manufactured goods amounted to 2 billion dollars whereas Iranian exports to Turkey comprised of natural gas amounted to 8 billion dollars. (http://www.mfa.gov.tr) The petroleum and natural gas imports from Iran have made up the highest part of trade relations. Economic relations are tended to develop particularly with political influences. Yet, still they do not have trade relations as expected.

Following global economic crisis challenging the whole world, in November 2008 Turkish and Iranian authorities signed a protocol to further improve bilateral economic cooperation within the framework of ECO.Turkish State Minister Mehmet Simsek said that this protocol was aimed at overcoming the negative effects of global economic crisis. Similarly Iranian Foreign Affairs Minister Mottaki pointed out that joint steps should be taken in the areas of transportation, banking, energy, industry and mining. (Haber Turk, 2008)

\section{CONCLUSION}

As the rhetoric of the governing elite in Turkey clearly illustrates, in the recent years the AK Party government's foreign policy towards the Middle East has two components: increasing influence of Turkey in the region; and developing good relations with neighbors. Consequently, the AK Party government has been willing to maintain and expand relations with Iran. Nevertheless, this strategy towards Iran involves strategic calculations rather than ideological considerations, which is based upon cooperation on energy security, military security and economy. Similar to Turkey, Iran wants to expand its sphere of influence in the neighboring regions and to become a key actor in regional politics, while also improving relations with Turkey. In general Iran's foreign policy towards the Middle East combines both ideologyoriented and pragmatic considerations. Yet, its approach toward Turkey has been mainly shaped by pragmatic considerations of preserving its security and maximizing its economic benefits. Nevertheless, it is not totally clear if Iran or Turkey is searching for a privileged role in the Middle East vis-à-vis the other.

Since 2002 both Iran and Turkey reinforced the possibility of expanding relations. As it is analyzed in this article, there are several indicators of rapprochement. Firstly, Turkey's relations with Iran have been transformed in the last years, as Tehran acted against the PKK and PJAK, and gave support to Turkey in the fight against the PKK. Secondly, Turkey has been searching for energy supply security and thus, considered Iran as an energy partner; while Iran has also supported this partnership. Lastly, economic cooperation has been beneficial for both Iran and Turkey. Yet, Iran has been aware of Turkey's increasing energy dependence and might use this advantage in conducting economic relations, while also collaborating with Turkey against the Kurdish separatists. In regard to the Iranian nuclear issue, Turkey does not oppose Iran's search for peaceful nuclear energy but also does not want spread of nuclear weapons in the Middle East. In short, with security and economic considerations cooperation between the two countries continues.

Although further cooperation against the PKK/ PJAK and further increase in bilateral trade and energy deals might be welcomed by both sides it is concluded that within long-term it is too early to speak about a mutual confidence and a multidimensional cooperation. Since their cooperation is restricted to a number of specific issues while they are searching for an enhanced regional role, their relations can be considered as a pragmatic rapprochement.

\section{END NOTES}

1. There is PKK (the Kurdistan Worker's Party) terrorism in Turkey and PJAK (the Party for a Free Life in Kurdistan) terrorism in Iran. The PKK is considered as a terrorist organization by a majority of the international community, including the EU and the US. The PJAK has recently threatened to start bomb attacks inside Iran if Tehran fails to stop anti-Kurdish policies.

2. The BTC pipeline, which was opened in May 2006, runs from the Sangachai terminal in Azerbaijan via Georgia to Ceyhan in Southern Turkey. The US has supported the BTC pipeline. The BS gas pipeline, which was opened in 2003, runs from Russia along the bottom of the Black Sea to Samsun in Northern Turkey. The Nabucco project is still in its initial planning phase and has been slowed by high costs and uncertainty over sources of supply. The construction of pipeline will start in 2009 and in the best scenario will be opened by 2012. The project aims to deliver natural gas from Central Asia and the Caspian region to Europe through a pipeline from Eastern Turkey via Romania, Bulgaria and Hungary to Austria. The EU and the US are strong supporters of the Nabucco pipeline. Construction of SC oil pipeline has started in the mid 2006. 


\section{REFERENCES}

Altunışı, M. (2008) “The Possibilities and Limits of Turkey's soft Power in the Middle East”, Insight Turkey, 10(2): 41-54.

Associated Press (2000) "Turkey To Buy Iranian Gas", 2 August.

Associated Press (2008) "Iran's Nuclear Negotiator Meets with Turkey's Foreign Minister”, 22 July.

Aras, B. \& Polat, R. K. (2007) "Turkey and The Middle East: Frontiers of the New Geographic Imagination", Australian Journal of International Affairs, 61(4): 471-488.

Aras, B. (2001) "Turkish Foreign Policy Toward Iran: Ideology and Foreign policy in Flux", Journal of Third World Studies, 18 (1): $87-105$.

Ayman, G. (2006) "Iran Nükleer Krizi ve Turkiye [Iran Nuclear Crisis and Turkey]”, Avrasya Dosyası, 12(2): 25-60.

Bar, A. (2006) "Turkish Foreign Policy Survey: Directions and Dilemmas in 2007", Perceptions, 11(3-4): 1-20.

Barysch, K. (2007) Turkey's Role in European Energy Security, London: Centre for European Reform Essays.

BBC News (2008) "Iran Leader in Landmark Iraq Trip", 2 March.

Bilici, A. (2008) "Iran Türkiye'yi geçti! (Iran is in front of Turkey)", Zaman, 12 March.

Bishku, M. B. (1999) "Turkey and Iran During the Cold War", Journal of Third World Studies, 16(1): 1-28.

Byman, D.; Chubin, S., Ehteshami, A. \& Green, J. (2001) Iran's Security Policy in the Post-Revolutionary Era, Santa Monica, CA: RAND.

Cagatay, S. (2009) “Turkiye, artik o eski Turkiye degil, (Turkey is not the same old Turkey)", Turkiye Newsweek, 18 January.

Calabrese, J. (1998) "Turkey and Iran: Limits of a stable Relationship”, British Journal of Middle Eastern Studies, 25(1): 75-94.

Chehabi, H. E. (2006) Distant Relations: Iran and Lebanon in the Last 500 Years, London: Centre for Lebanese Studies in association with I.B. Tauris Publishers.

Christian Science Monitor (2006) "Caught in the Fray: Turkey Enters Debate on Iran's Nuclear Programme”, 2 February.

Clawson, P. \& Michael R. (2005) Eternal Iran: Continuity and Chaos, New York: Palgrave Macmillan.

Davutoglu, A. (2008) "Turkey's Foreign Policy Vision: An Assessment of 2007”, Insight Turkey, 10(1): 77-97.

Economist (2007) “Turkey and Iran: Too Energetic a Friendship”, 23 August.

Efegil, E. \& Stone, L. A. (2003) "Iran and Turkey in Central Asia: Opportunities for Rapprochement in the post-Cold War Era”, Journal of Third World Studies, 20(1): 55-77.

Emerson, M. \& Tocci, N. (2004) "Turkey as a Bridgehead and Spearhead: Integrating EU and Turkish Foreign Policy”, EU Turkey Working Papers, No. 1, Brussels: Centre for European Policy Studies.
Ehteshami, A. \& Raymond, H. A. (2002) Syria and Iran: Middle Powers in a Penetrated Regional System, London: Routledge.

Guardian (2008) "US must Share Power in New World Order, Says Turkey's Controversial President”, 16 August.

Gungor, N. (2008) “Ahmedinejad's Visit to Turkey: Two Neighbors Oscillate Between Threat and Friendship", SETA (Foundation for Political, Economic and Social Research) Policy Brief, No.23.

Haberturk Net (2008) “Turkey-Iran Security Meeting Begins”, 15 April.

Jenkins, G. (2008) “Turkey and Iran Expected to Boost Security Cooperation”, Eurasia Daily Monitor, 14 April.

Karaca, N. B. (2009) "Iran-Turkiye ilişkileri ve bazı soru işaretleri (Turkey-Iran Relations and some question-marks)", Haber Turk, 10 October.

Karmon, E. (1997) "Radical Islamic political groups in Turkey", Middle East Review of International Affairs (MERIA), 1(4).

Kibaroglu, M. (2004), "Iran's Nuclear Programme may Trigger the Young Turks to Think Nuclear", http:// www.carnegieendowment.org/npp/publications/index. cfm?fa=view\&id=16284, (15. 04. 2009).

Laqueur, W. (2002) The New Terrorism: Fanaticism and the Arms of Mass Destruction, London: Oxford University Press.

Larrabee, F. S. (2007) "Turkey Rediscovers the Middle East", Foreign Affairs, 86(4): 103-114.

Mango, A. (2005) Turkey and the War on Terror, London and New York: Routledge.

Oguzlu, T. (2007) "Soft Power in Turkish Foreign Policy", Australian Journal of International Affairs, 61(1): 81-97.

Olson, R. (2004) Turkey-Iran Relations 1979-2004: Revolution, Ideology, War, Coups and Geopolitics, Costa Mesa, CA: Mazda Publishers.

Olson, R. (2002a) "Turkey-Iran Relations, 2000-2001: The Caspian, Azerbaijan and the Kurds", Middle East Policy, 9(2): 111-129.

Olson, R. (2002b) "The Azeri Question and Turkey-Iran Relations, 2000-2002", Nationalism and Ethnic Politics, 8(4): 61-85.

Olson, R. (2000) “Turkey-Iran Relations, 1997 to 2000: the Kurdish and Islamist Questions", Third World Quarterly, 21(5): 871-890.

Ozcan, N. A. (1999) “Iran’ın Türkiye Politikasında Ucuz Ama Etkili bir Manivela: PKK (A Cheap but Influent Level in Turkey Policy of Iran: the PKK)", Avrasya Dosyası, 5(3): 32543.

Ozacan, G. (2004) “Turkey’s Changing Neighbourhood Policy”, The Turkish Yearbook of International Relations, 35: 1-15.

Ozel, S. (2009) “Doğu-Batı Terazisinde Denge Şart (Equilibrium is Necessary in East-West Balance)", Haber Turk, 30 October.

Ramazani, R. K. (2004) "Ideology and Pragmatism in Iran's Foreign Policy”, Middle East Journal, 58(4): 1-11. 
Reuters (2008) “Turkey says US Nuclear Policy Strengthens Iran”, 26 January.

Sarikaya, M. (2009) "Gul'den Eksen Model Tespiti (Gul Discovers Axis Model)", Haber Turk, 5 November.

Schleifer, Y. (2006) "Caught in the Fray: Turkey Enters the Debate on Iran's Nuclear Programme", The Christian Science Monitor, 2 February.

Tan, N. (2006) “Iran'ın Nükleer Programı Bağlamında Ülkemizin Nükleer Silah Üretimine Yönelip Yönelmeyeceği Hakkında Dışişleri Bakanlığı Sözcüsü Namık Tan'ın Bir Soruya Cevabı [The Answer of Namik Tan, Foreign Policy Ministry spokesman, to a question: if Turkey will Produce Nuclear Weapons as a Result of Iranian Nuclear Programme]", http:// www.mfa.gov.tr/sc_2---11-subat-2006_-iran_in-nukleerprogrami-baglaminda_... $(20,04,2009)$.

Tank, P. (2005) "The Effects of the Iraq War on the Kurdish Issue in Turkey", Conflict, Security and Development, 5(1): 69-
86.

TDN (Turkish Daily News) (2008a) "Turkey, Iran Work Together Against PKK, Gen. Basbug says”, 6 June.

TDN (Turkish Daily News) (2008b) "Russia Boosts Gas Exports to Turkey After Blast", 28 May.

TDN (Turkish Daily News) (2007) "Energy Deal with Iran Dominates PM's Agenda”, 28 September.

Turkey Analyst (2008) "Between Political Crises: Turkish Energy Policy", 23 April.

Uygur, H. (February 2008) "Iran's Nuclear Ambitions and Turkey”, Seta Policy Brief, 7: 1-7.

Vick, K. (2006) "Energy, Iran spur Turkey's Revival of Nuclear Plans", Washington Post, 7 March.

Yetkin, M. (2008) “US Expectations from Turkey and Iran”, Turkish Daily News, 1 May. 